\title{
Author Index Volume 9 (2011)
}

The issue number is given in front of the pagination

Adamson, D.C., B.A.K. Rasheed, R.E. McLendon and D.D. Bigner, Central nervous system (1-6) 193210

Anderson, K.S., see Cole, K. (1-6) 177-192

Anton, K., see Crichton, D.J. (1-6) 511-530

Bailey, J.M., see Remmers, N. (1-6) 421-440

Balic, M., A. Williams, N. Dandachi and R.J. Cote, Micrometastasis: Detection methods and clinical importance (1-6) 397-419

Bell, W.C., see Grizzle, W.E. (1-6) 531-549

Bigner, D.D., see Adamson, D.C. (1-6) 193-210

Block, T., A.S. Mehta and W.T. London, Hepatocellular carcinoma of the liver (1-6) 375-383

Bogenrieder, T. and M. Herlyn, The molecular pathology of cutaneous melanoma (1-6) 267-286

Brambilla, E., see Gazdar, A.F. (1-6) 385-396

Bumpers, H.L., see Manne, U. (1-6) 235-265

Cairns, P., Renal cell carcinoma (1-6) 461-473

Carmona, F.J. and M. Esteller, DNA methylation in early neoplasia (1-6) 101-111

Cazares, L.H., R.R. Drake, A. Esquela-Kirscher, R.S. Lance, O.J. Semmes and D.A. Troyer, Molecular pathology of prostate cancer (1-6) 441-459

Chen, Q.C., see Zhao, X.F. (1-6) 341-374

Chiosea, S.I., see Park, B.J. (1-6) 325-339

Cole, K., M. Tabernero and K.S. Anderson, Biologic characteristics of premalignant breast disease (16) 177-192

Cote, R.J., see Balic, M. (1-6) 397-419

Cramer, D.W., see Merritt, M.A. (1-6) 287-305

Crichton, D.J., C.A. Mattmann, M. Thornquist, K. Anton and J.S. Hughes, Bioinformatics: Biomarkers of early detection (1-6) 511-530

Czerniak, B., Molecular pathology and biomarkers of bladder cancer (1-6) 159-176

Czerniak, B.A., see Powers, M. (1-6) 475-491
Dandachi, N., see Balic, M. (1-6) 397-419

David, S. and S.J. Meltzer, Stomach - Genetic and epigenetic alterations of preneoplastic and neoplastic lesions (1-6) 493-507

Drake, R.R., see Cazares, L.H. (1-6) 441-459

Esquela-Kirscher, A., see Cazares, L.H. (1-6) 441-459

Esteller, M., see Carmona, F.J. (1-6) 101-111

FitzGerald, K.T., see Natarajan, T.G. (1-6) 65-99

Ganesan, N., see Natarajan, T.G. (1-6) 65-99

Gazdar, A.F. and E. Brambilla, Preneoplasia of lung cancer (1-6) 385-396

Grandis, J.R., see Park, B.J. (1-6) 325-339

Grizzle, W.E., S. Srivastava and U. Manne, The biology of incipient, pre-invasive or intraepithelial neoplasia (1-6) 21-39

Grizzle, W.E., S. Srivastava and U. Manne, Translational pathology of neoplasia (1-6) 7-20

Grizzle, W.E., see Manne, U. (1-6) 235-265

Grizzle, W.E., see Srivastava, S. (1-6) 1-4

Grizzle, W.E., see Srivastava, S. (1-6) 41-64

Grizzle, W.E., W.C. Bell and K.C. Sexton, Issues in collecting, processing and storing human tissues and associated information to support biomedical research (1-6) 531-549

Herlyn, M., see Bogenrieder, T. (1-6) 267-286

Hollingsworth, M.A., see Remmers, N. (1-6) 421-440

Hopwood, V., see Sen, S. (1-6) 113-132

Hughes, J.S., see Crichton, D.J. (1-6) 511-530

Katkoori, V.R., see Manne, U. (1-6) 235-265

Lance, R.S., see Cazares, L.H. (1-6) 441-459

Lazar, A.J., see Powers, M. (1-6) 475-491

Liu, A.Y., L.E. Pascal, R.Z. Vêncio and E.F. Vêncio, Stromal-epithelial interactions in early neoplasia (1-6) 141-155 
London, W.T., see Block, T. (1-6) 375-383

Lopez-Terrada, D., see Powers, M. (1-6) 475-491

López-Terrada, D., see Rushton, J. (1-6) 211-234

Manne, U., C. Shanmugam, V.R. Katkoori, H.L. Bumpers and W.E. Grizzle, Development and progression of colorectal neoplasia (1-6) 235-265

Manne, U., see Grizzle, W.E. (1-6) 21-39

Manne, U., see Grizzle, W.E. (1-6) 7-20

Mattmann, C.A., see Crichton, D.J. (1-6) 511-530

McLendon, R.E., see Adamson, D.C. (1-6) 193-210

Mehta, A.S., see Block, T. (1-6) 375-383

Meltzer, S.J., see David, S. (1-6) 493-507

Merritt, M.A. and D.W. Cramer, Molecular pathogenesis of endometrial and ovarian cancer (1-6) 287305

Mohr, A.M., see Remmers, N. (1-6) 421-440

Natarajan, T.G., N. Ganesan and K.T. FitzGerald, Cancer stem cells and markers: New model of tumorigenesis with therapeutic implications (1-6) 65-99

Park, B.J., S.I. Chiosea and J.R. Grandis, Molecular changes in the multistage pathogenesis of head and neck cancer (1-6) 325-339

Pascal, L.E., see Liu, A.Y. (1-6) 141-155

Powers, M., W. Zhang, D. Lopez-Terrada, B.A. Czerniak and A.J. Lazar, The molecular pathology of sarcomas (1-6) 475-491

Rasheed, B.A.K., see Adamson, D.C. (1-6) 193-210

Reid, B.J., Early events during neoplastic progression in Barrett's esophagus (1-6) 307-324

Reitz, M., see Zhao, X.F. (1-6) 341-374

Remmers, N., J.M. Bailey, A.M. Mohr and M.A. Hollingsworth, Molecular pathology of early pancreatic cancer (1-6) 421-440
Rushton, J. and D. López-Terrada, Molecular and genetic basis of childhood cancer (1-6) 211-234

Semmes, O.J., see Cazares, L.H. (1-6) 441-459

Sen, S. and V. Hopwood, Molecular cytogenetic evidence for multistep tumorigenesis: Implications for risk assessment and early detection (1-6) 113132

Sexton, K.C., see Grizzle, W.E. (1-6) 531-549

Shanmugam, C., see Manne, U. (1-6) 235-265

Srivastava, S. and W.E. Grizzle, Biomarkers and the genetics of early neoplastic lesions (1-6) 41-64

Srivastava, S. and W.E. Grizzle, Editorial (1-6) 1-4

Srivastava, S., see Grizzle, W.E. (1-6) 21-39

Srivastava, S., see Grizzle, W.E. (1-6) 7-20

Srivastava, S., see Wang, W. (1-6) 133-140

Stass, S., see Zhao, X.F. (1-6) 341-374

Tabernero, M., see Cole, K. (1-6) 177-192

Thornquist, M., see Crichton, D.J. (1-6) 511-530

Troyer, D.A., see Cazares, L.H. (1-6) 441-459

Vêncio, R.Z., see Liu, A.Y. (1-6) 141-155

Vêncio, E.F., see Liu, A.Y. (1-6) 141-155

Wang, W. and S. Srivastava, Noncoding RNAs in molecular characterization of cancer preneoplasia (1-6) 133-140

Williams, A., see Balic, M. (1-6) 397-419

Zhang, W., see Powers, M. (1-6) 475-491

Zhao, X.F., M. Reitz, Q.C. Chen and S. Stass, Pathogenesis of early leukemia and lymphoma (1-6) 341-374 